УДК 598.261.7:636.594: 636.08 (477)

(C) 2014

\author{
Фролов Д. О., аспірант \\ (науковий керівник - кандидат біологічних наук О. П. Корж )
}

Запорізький національний університет

\title{
ЕКОНОМІЧНІ ПРОБЛЕМИ ФАЗАНІВНИЦТВА В УКРАЇНІ
}

\section{Рецензент - доктор сільськогосподарських наук П. В. Писаренко}

Економічна ефективність господарства залежить від дотримання технології вирощування птахів. 3 а оптимізаиії процесу вирощування мисливського фазана на господарстві «Скіф» протягом 3-х років вдалося збільшити кількість пташенят від однієї самки на $185 \%$. У випадку дотримання технології вирощування мисливського фазана на всіх господарствах України кількість ділового молодняку підвищиться на 113103. У перерахунку на грошові показники, економічний ефект для Украйні в иілому складатиме понад13,3 млн грн.

Ключові слова: мисливський фазан, итучне розведення дичини, технологія вирощування nmaxis.

Постановка проблеми. Мисливський фазан на території України став масовим об’єктом полювання лише після освоєння засобів його штучного розведення та регулярних випусків в угіддя. Літус I. С. [11], аналізуючи стан популяцій цього виду в Україні, вважав, що за 20 років (із 1951 по $1971)$ здійснений випуск в обсязі понад 370 тис. особин $є$ достатнім для розселення територією всієї держави. До того ж навіть сьогодні наявна чисельність не забезпечує повністю потреби мисливців.

За часів Радянського Союзу було розроблено технологію промислового вирощування мисливського фазана [3] та нормативні вимоги на добовий молодняк та інкубаційне яйце [12]. На той час УССР вважалася однією з найбільш перспективних республік щодо розведення мисливського фазана.

Кризові явища в економіці нашої країни, що розпочалися після розпаду Радянського Союзу, призвели до того, що штучне вирощування мисливського фазана зазнало значного занепаду. У свою чергу, це призвело до суттєвого скорочення об'ємів вирощування мисливського фазана на господарствах України.

Тільки починаючи 3 2000-х років, у державі спостерігається зростання кількості господарств iз розведення фазана. Вже у 2009 році їх кількість сягала 27, на яких загалом утримувалося 19,8 тис. основного поголів'я. У цьому ж році інтродуковано було 15,45 тис. голів мисливського фазана [14]. У 2013 році кількість господарств із розведення фазана сягала вже 45 , утримувалося при цьому лише 15,185 тис. голів основного поголів'я та інтродуковано було 10,56 тис. голів. Тобто, у разі зростання кількості господарств їх ефективність та показники виробництва за п'ять останніх років знижуються.

Чисельність мисливського фазана у природних умовах весь час коливалась на досить низькому рівні. Більше того, за останні роки кількість цих птахів в угіддях скоротилася на 13,79\% iз 406 тисяч (1995 рік) до 347 тисяч особин зараз. При цьому в Україні мисливцями впольовується близько 35 тисяч фазанів. Для порівняння, у Франції, яка за площею угідь менша за нашу країну, щорічно випускається 12-15 мільйонів особин цього птаха, а впольовується близько 5 мільйонів [16]. Виходячи з вищенаведеного матеріалу, актуальним залишається визначення проблем фазанівництва України.

Аналіз основних досліджень і публікацій, у яких започатковано розв'язання проблеми. В Україні роботи з оцінки економічної ефективності вирощування мисливського фазана в умоваx ex-situ практично не здійснювалися. Наявні роботи присвячені історії фазанівництва $[1,2]$ чи деяким морфологічним аспектам природних популяцій [4, 8-11], або лише впливу окремих факторів на продуктивні показники мисливського фазана в умовах ex-situ [5-7]. Робіт із комплексної оцінки економічних показників вирощування в умовах ex-situ мисливського фазана, на жаль, немає.

Мета і завдання досліджень. Метою роботи було визначення економічних проблем штучного розведення мисливського фазана в Україні.

Для реалізації мети були поставлено наступні задачі: вдосконалення роботи фазанарію впродовж трьох сезонів та аналіз економічної успішності розведення мисливського фазана в Україні.

Матеріал і методика досліджень. Нами було проаналізовано основні показники роботи фазанарію мисливського господарства «Скіф» у 2010 


\section{СТОРІНКА МОЛОДОГО ВЧЕНОГО}

- 2012 роках. Аналізувалося дотримання найважливіших елементів виробничого процесу. За нашими рекомендаціями у 2010 році для оптимізації вирощування на дослідному господарстві було відкореговано статево-вікову структуру батьківського поголів'я з 1:5 до 1:9. Крім цього, було вибракувано тварин, які не відповідали вимогам за екстер'єрними показниками, а також виправлено час формування сімей (строк формування сімей перенесено з кінця березня на другу декаду лютого). Нами було доопрацьовано кормові раціони батьківського поголів'я, а саме кількість протеїну підвищено з $16 \%$ до $20 \%$. Також у репродуктивний період додатково у вольєрах додавалися подрібнені черепашки в необмеженій кількості.

Проводилася селекційна робота за морфометричними показниками яєць та дефектами. Було відкореговано умови зберігання яєць (температуру в яйцесховищі $3+26^{\circ} \mathrm{C}$ зменшено до $+20^{\circ} \mathrm{C}$ ). Інкубаційний режим також зазнав змін: температуру в інкубаторі $3+38^{\circ} \mathrm{C}$ змінено на $+37,8^{\circ} \mathrm{C}$, а вологість $370 \%$ підвищено до 74-76\%. Під час утримання молодняка було змінено годування, а саме вміст сирого протеїну підвищено до $26 \%$.

Оскільки в якості базового корму використовувався ПК-5 для бройлерних курчат із досить великою фракцією гранул, у перший тиждень вирощування фазаненят корм додатково подрібнювали, зменшуючи гранули до 2-3 мм. Також у брудерному приміщені під лампами обігріву було піднято температуру до $+35^{\circ} \mathrm{C}$.

Крім цього нами було використано дані держкомстату України [13], а саме кількість основного та реалізованого поголів'я мисливського фазана.

Результати досліджень. У 2010 році в мисливському господарстві «Скіф» від однієї самки було отримано в середньому 31,36 яєць за сезон та лише 3,85 дорослих птахів.

Слід зазначити, що отримані результати були в 1,8 разу вищі за середні для України. Зміни технологічного процесу на господарстві «Скіф» дали змогу за 3 роки суттєво збільшити ефективність його роботи (табл. 1). Вдалося збільшити яйценосність самок за сезон у середньому на 8,19\%.

Процеси підвищення яйценосності супроводжуються незначним зростанням середньої маси яєць за досліджений період на 3,5 \%, а також зменшенням кількості дефектів шкаралупи та частки яєць із блакитним і білим забарвленням. Завдяки цьому відбувається збільшення придатності яєць до інкубації в середньому на $32,2 \%$.

Значно підвищується відсоток виводу пташенят, який у 2012 році виявився на $36 \%$ вищим, порівняно з 2010 роком.

Процеси, пов'язані 3 покращанням якості яєць, також позначаються на масі пташенят, - за досліджений період цей показник зростає на $3,12 \%$.

\section{1. Розрахунки економічної користі під час запровадження системи управління метапопуляцією на прикладі господарства «Скіф»}

\begin{tabular}{|c|c|c|c|c|}
\hline \multirow{2}{*}{$№$ п/п } & Показник & \multicolumn{2}{|c|}{ Рік досліджень } & \multirow{2}{*}{$\begin{array}{c}\text { Економічний } \\
\text { ефект }\end{array}$} \\
\cline { 2 - 4 } & 2 & 2010 & 2012 & 5 \\
\hline 1 & Кількість яєць на 1 самку за сезон \\
(шт.) & 31,36 & 33,93 & 2,57 \\
\hline 2 & Середня маса яєць (г) & 29,36 & 30,39 & 1,03 \\
\hline 3 & Придатність яєць до інкубації (\%) & 69,5 & 85 & 15 \\
\hline 4 & $\begin{array}{c}\text { Кількість придатних яєць до інкубації } \\
\text { на 1 самку за сезон (шт.) }\end{array}$ & 21,8 & 28,84 & 7,04 \\
\hline 5 & Виводимість яєць (\%) & 31 & 67 & 36 \\
\hline 6 & $\begin{array}{c}\text { Відсоток пташенят придатних до } \\
\text { подальшого вирощування (\%) }\end{array}$ & 32 & 33 & 1 \\
\hline 7 & $\begin{array}{c}\text { Кількість пташенят придатних до } \\
\text { вирощування (шт.) }\end{array}$ & 4,52 & 12,94 & 8,42 \\
\hline 8 & $\begin{array}{c}\text { Збереженість пташенят під час } \\
\text { вирощування (\%) }\end{array}$ & 85 & 85 & 0 \\
\hline 9 & $\begin{array}{c}\text { Кількість дорослих птахів отриманих } \\
\text { від однієї самки за сезон (шт.) }\end{array}$ & 3,85 & 11,00 & 7,15 \\
\hline
\end{tabular}




\section{СТОРІНКА МОЛОДОГО ВЧЕНОГО}

За даними Держкомстату України, природна чисельність популяції мисливського фазана коливається на рівні 325 тисяч (рис. 1). За вартості ліцензії на здобування мисливського фазана в середньому 75 грн та здобуванні близько 45 тис., сума, отримана за полювання на фазана, становить 3,375 млн гривень. При цьому витрати на штучне розведення мисливського фазана в 2013 році сягали 787,2 тис. гривень, що склало $23 \%$ надходжень від полювання. Слід зазначити, що витрати у 2009 році були вищими й сягали 1275,6 тис. гривень без урахування інфляції. За досліджений період кількість фазанаріїв збільшилася 38 до 45, тобто в 9 разів.
За такої динаміки зростання господарств із вирощування мисливського фазана пропорційно повинно була б зростати й кількість товарного молодняка, але цей показник за досліджений період зріс всього в 2,5 разу (рис. 2). Крім цього слід зазначити, що здобувається фазанів у 2 рази більше, ніж інтродукується. Статистичні дані на 2013 рік, свідчать, що кількість основного поголів'я фазанів на фазанаріях сягала 15189 особин, а діловий вихід молодняка склав 25395. Таким чином, за сезон від однієї самки було отримано в середньому лише 2,01 фазанів. Для порівняння, в Європейських країнах цей показник дорівнює 20 - 25 особин на самку за сезон [15].

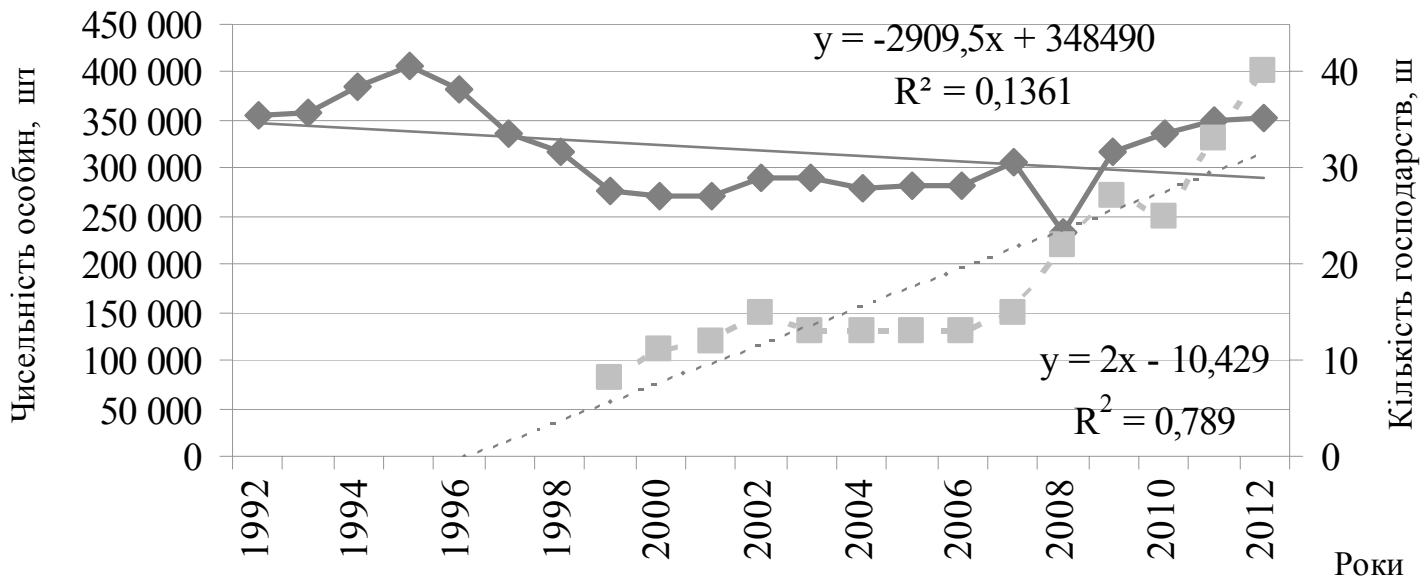

$\sim$ Чисельність фазана в природі _ = - - К - Кілікість господарств

Рис. 1. Динаміка природної чисельності та кількості фазанаріїв в Украӥні

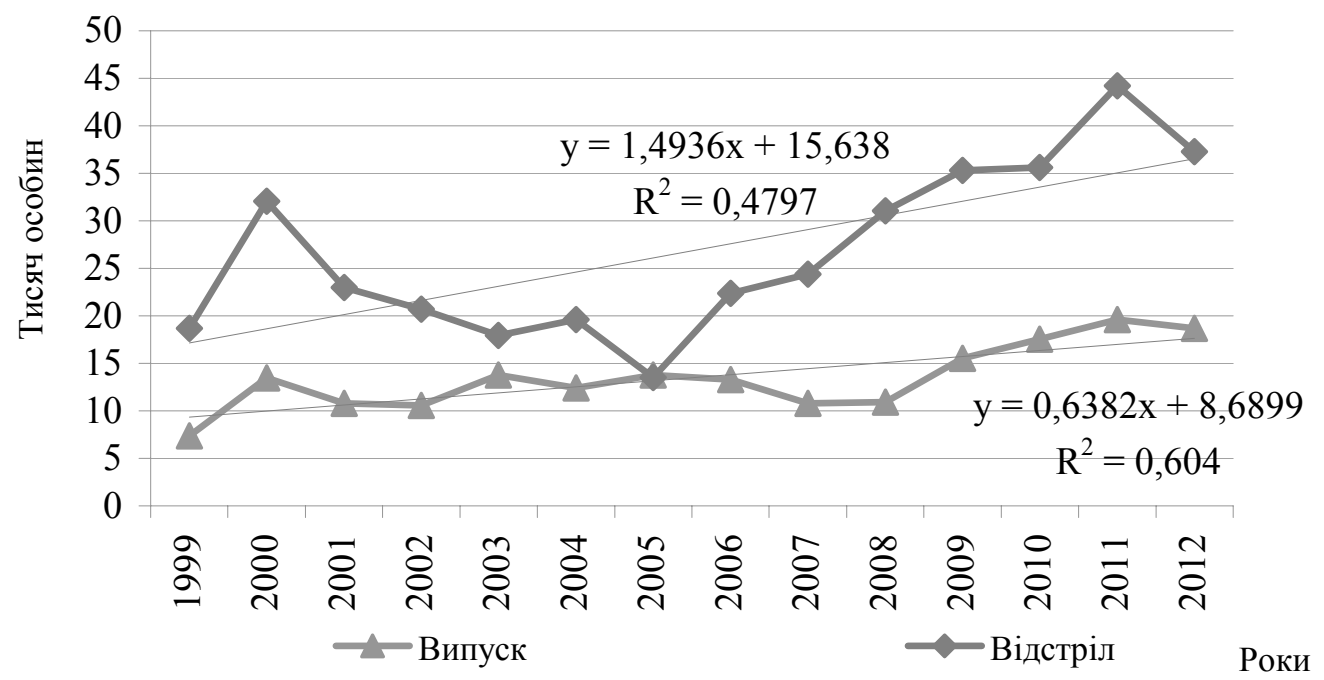

Рис. 2. Динаміка природної чисельності, здобутих та розселених фазанів в Украӥні 


\section{СТОРІНКА МОЛОДОГО ВЧЕНОГО}

У випадку дотримання всіма господарствами України технології вирощування мисливського фазана економічний ефект становив понад 113 тис. особин ділового молодняку. У перерахунку на грошові показники, економічний ефект по Україні в цілому складатиме близько 13,3 млн. грн., що майже втричі більше, ніж прибуток мисливського господарства за надання послуг із полювання на даний вид.

Висновки: 1. Економічна ефективність на фазанарії залежить від технології дотримання вирощування птахів. За оптимізації процесу утримання мисливського фазана на господарстві «Скіф» протягом трьох років вдалося на 185 \% збільшити отримання пташенят від однієї самки. У

\section{БІБЛІОГРАФІЯ}

1. Васильєва О. О. Історія та перспективи розвитку фазанівництва в галузі птахівництва України / О. О. Васильєва // Вісник Полтавської державної аграрної академії, 2009. - №2. - С 58-62.

2. Васильєва О.О. Розведення фазанів - перспективний напрям сучасного птахівництва України / О. О. Васильєва : збірка матеріалів Міжнародної науково-практичної конференції [Промислове і декоративне птахівництво : проблеми та перспективи проведеної у рамках фестивалю «Пташиний двір» ] (Кам'янець-Подільський, 12 13 жовтня 2011 р.) / Міністерство аграрної політики і продовольства України. - Кам'янецьПодільський, 2011. - С. 10-11.

3. Габузов О. С. Искусственное дичеразведение / О. С. Габузов. - Иркутск, 1984. -51 с.

4. Дзизюк $O$. Фазан звичайний phasianus colchicus L. у різних мисливських угіддях / О. Дзизюк // Вісник Львівського університету. Серія біологічна, 2005. - Вип. 39. - С. 135-140.

5. Корж А. П. Управление состоянием метапопуляции охотничьего фазана в условиях $e x-$ situ / А. П. Корж // Вісник Дніпропетровського державного аграрного університету. - Дніпропетровськ, 2006. - С. 134-138.

6. Корж О. П. Зоокультура як наукова основа збереження рідкісних та зникаючих видів / О. П. Корж, Д. О. Фролов // Питання біоіндикації та екології. - 2008. - Випуск 13. - № 2. - С. 151-157.

7. Корж О. П. Теоретичні засади зоотехнічного розділу фазанівництва / О. П. Корж // Наукові доповіді НУБіП. - 2012. - №2 (31) http://www. nbuv.gov.ua/e-journals/Nd/2012_2/12kop.pdf

8. Курочкин С. Л. Аклиматизация фазана на юге Украины и Молдавии / С. Л. Курочкин // Разведение и создание новых популяций редких и ценных видов животных. - Ашхабад, 1982. - цьому разі, економічний ефект для господарства складав 270 тис. гривень.

2. За досліджений період кількість фазанаріїв збільшилася 38 до 45, тобто в 9 разів. У цьому випадку кількість товарного молодняка зросла лише в 2,5 разу. Витрати на штучне розведення мисливського фазана в 2013 році сягали 787,2 тис. гривень, що склало 23 \% відсотка прибутку від полювання.

3. У випадку дотримання всіма господарствами України технології вирощування мисливського фазана, економічний ефект складав би понад 113 тис. особин ділового молодняку: у перерахунку на грошові показники для України буде сягати близько 13,3 млн гривень.

\section{C. $131-136$.}

9. Курочкин С. Л. Создание популяции фазана в Причерноморье путем интродукции искусственно выращенных птиц / С. Л. Курочкин // Зоокультура ценных и редких видов птиц и зверей. - М., 1989. C. $172-181$.

10. Курочкин С. Л. Особенности постэмбрионального развития обыкновенного фазана в северозападном Причерноморье / С. Л. Курочкин // Дичеразведение в охотничьем хозяйстве. - М. : Изд-во ЦНИЛ Главохоты РСФСР, 1985. - С. 85-101.

11. Литус И. Е. Акклиматизация фазанов на Украине / И. Е. Литус : автореф. дис. на здобуття кандидата биол. наук. - К., 1973. - 24 с.

12. Габузов $O$. C. Нормативные требования на инкубационные яйца и суточный молодняк охотничьего (гибридного) фазана / О. С. Габузов, В. П. Юрченко, В. С. Иванова и др. [утверждено нач. Главного управления охот. хоз. и заповедников при Совете Менистров В. И Фертиковым]. М. : Изд-во Упрполиграфиздата Мособлисполкома, 1987. $-4 \mathrm{c}$.

13. Сайт Державної служби статистики України [Електронний ресурс]. - Режим доступу : http://www.ukrstat.gov.ua/druk/publicat/kat_u/2014 /bl/04/bl_misl_13.zip

14. Статистичний збірник «Довкілля України» за 2004 рік / Державний комітет статистики України / за ред. Ю. М. Остапчука. - К. : 2005. $260 \mathrm{c}$.

15. Estienne H. L'élévage du faisant / H. Estienne // La Revve de la chasse, 1970. - № 271. - P. 26-29.

16. Melin J.-M. Selection sur la couvaison naturelle darts une souehe de faisans (Phasianus colchicus) elevée en captivité / J.-M. Melin, J.-P. Damange // Z. Jagdwiss. - 2002. - № 48. P. $327-339$. 